\title{
РЕЦЕНЗИИ
}

\section{The Multi-Confessional Policy of the Provisional Government}

\author{
G. L. Freeze
}

For citation: Freeze G. L. The Multi-Confessional Policy of the Provisional Government. Vestnik of Saint Petersburg University. History, 2020, vol. 65, iss. 1, pp.310-317.

https://doi.org/10.21638/11701/spbu02.2020.118

The post-Soviet era has witnessed an exponential growth in scholarly research on the history of religion in Russia, especially with respect to church-state relations. There is, however, one striking exception: the period of the Provisional Government (March-October 1917), which has thus far attracted little attention. Whereas the Russian Orthodox Church has indeed been the target of substantial scholarship (especially in preparation for the Church Sobor), the same cannot be said of other confessions. That huge lacuna is addressed in this new collection of documents, compiled by M.A. Babkin (doctor of historical sciences), and it constitutes an extremely valuable contribution to the study of the complex confessional politics unleashed by the February Revolution. The collection is comprised of 251 main documents (and several supplementary texts) and offers a systematic collection of laws, draft laws, inter-agency papers, and some materials from religious associations. More than half of the documents are published for the first time; these pertain not only to general policy and the Russian Orthodox Church, but to fifteen other Christian and non-Christian confessions. On the basis of these documents it is possible to follow the development - and problems - in the confessional policy of the Provisional Government. The principal shortcoming of this work is the dearth of materials on the implementation of policy and the reaction by various social and confessional groups. After all, it is important not only to know what was deliberated and decreed "at the

Gregory L. Freeze - PhD, Professor of History, Brandeis University, GF11, Waltham, Massachusetts, USA; Visiting Research Fellow, St. Petersburg University, 7-9, Universitetskaia nab., St. Petersburg, 199034, Russian Federation; freeze@brandeis.edu

Грегори Л. Фриз - PhD, профессор истории, Брандейский университет, США, Уолтем, Массачусетс, США; приглашенный исследователь, Санкт-Петербургский государственный университет, Российская Федерация, 199034, Санкт-Петербург, Университетская наб., 7-9; freeze@brandeis.edu

This research was supported by grant No. 15-18-00119 from the Russian Science Foundation. Исследование выполнено при поддержке гранта Российского научного фонда № 15-18-00119.

(c) Санкт-Петербургский государственный университет, 2020 
top," but how society perceived and responded to the confessional policy of the Provisional Government.

Keywords: Provisional Government, confessional policy, freedom of conscience, Russian Orthodox Church, Lutheran Church, sectarians.

\title{
Конфессиональная политика Временного правительства
}

\author{
Г. Л. Фриз
}

Для цитирования: Freeze G.L. The Multi-Confessional Policy of the Provisional Government // Вестник Санкт-Петербургского университета. История. 2020. Т.65. Вып. 1. С.310-317. https://doi.org/10.21638/11701/spbu02.2020.118

В постсоветское время наблюдается экспоненциальный рост научных исследований по истории религии в России, особенно в области церковно-государственных отношений. Но есть одно поразительное исключение: период Временного правительства (март - октябрь 1917 г.), который до сих пор привлекал мало внимания. Несмотря на то что имеются основательные исследования о Русской православной церкви (особенно в связи с подготовой и проведением Церковного Собора), нельзя сказать то же самое о других конфессиях. Февральская революция ставила ребром вопрос о свободе совести и правах неправославных конфессий. И последние, естественно, боролись за полное признание своих прав, которые, несмотря на закон 17 апреля 1905 г., были только частично реализованы, и все еще ощущали дискриминацию, а порой и открытое преследование. Новый сборник документов, подготовленный доктором исторических наук М.А.Бабкиным, является весьма ценным вкладом в изучение сложного, многоконфессионального вопроса, политики Временного правительства и все возрастающих ожиданий и требований разных религиозных групп. Состоящий из 251 главного документа (и несколько добавочных текстов), сборник предлагает систематическое собрание законов, законопроектов и межведомственного делопроизводста, а также несколько документов со стороны общества и религиозных организаций. Больше половины документов публикуются впервые; имеются в виду не только общая политика, но и конкретные конфессии (Русская православная церковь и 15 других инославных и иноверных исповеданий). На основе данных источников можно проследить развитие многоконфессиональной политики Временного правительства и проблемы в ней. Главный недостаток исследуемой работы - это слабое представление о проведении в жизнь данного законодательства и об отношении разных социальных и религиозных групп к новому «секулярному» государству. Важно не только то, что политики «наверху» писали, а как общество воспринимало и реагировало на конфессиональную политику Временного правительства.

Ключевые слова: Временное правительство, конфессиональная политика, свобода совести, Русская православная церковь, Лютеранская церковь, сектанты.

Since the fall of the Soviet Union, research on the history of religion, and especially the Russian Orthodox Church, has increased exponentially - both inside Russia and abroad $^{1}$. While much has been done to shed light on the Orthodox Church and other confessions, scholarship on the religious policy of the Provisional Government is quite mod-

${ }^{1}$ For data on the number of dissertations alone, see: Freeze G. "Votserkovlenie" 1917 goda: tserkovnyi krizis i prikhodskaia revoliutsiia // Gosudarstvo, religiia, tserkov’ v Rossii i za rubezhom. 2019. No. 1/2 (39). P. 30-58. 
est. With only a few exceptions, notably the dissertations by O. Iu. Red'kina and A. V.Sokolov $^{2}$, most scholarship has focused on the internal politics of the various confessions, especially the turmoil in the Russian Orthodox Church, and shown only marginal interest in the state and its role. That neglect reflects a long-standing disdain for the Provisional Government, which has been generally dismissed as irrelevant to the broader political and social dynamics that ultimately led to the Bolshevik seizure of power in October. Only recently have scholars finally published the journals of the Provisional Government and other documents, such as the sessions of the Juridical Council (Iuridicheskoe soveshchanie) that were critical in the government's decision-making ${ }^{3}$. But a systematic collection of documents on the confessional policy has been lacking.

With the publication of a volume dedicated to the confessional policy of the Provisional Government ${ }^{4}$, M. A. Babkin has undertaken a herculean effort to fill that gap. He has previously published extensively on the role of the Orthodox Church in the February Revolution and its aftermath, including a very substantial volume of documents ${ }^{5}$. This volume contains 253 documents (including two that repeat) as well as attachments and texts tucked inside the extensive commentaries. Including the main documents and various appended texts (total of 272$)^{6}$, more than half (57.7 percent) were previously unpublished; the balance appeared in contemporary or later publications. More than a third of the latter are also available in the recent 5-volume "journals" (zhurnaly) of the Provisional Government, and some duplicate the current project to publish the minutes of the Juridical Council ${ }^{7}$. More than half of the archival documents come from the Gosudarstvennyi arkhiv Rossiiskoi Federatsii (GARF), somewhat less from the Rossiiskii gosudarstvennyi istoricheskii arkhiv (RGIA), and a handful from the Rossiiskii gosudarstvennyi voennoistorichesikii arkhiv (RGVIA). It bears nothing that Babkin did not limit his search to archives and official periodicals, but in a few cases drew upon materials published in the religious and secular press ${ }^{8}$.

This volume seeks to provide a comprehensive guide to state policy not only on the Russian Orthodox Church, but on other Christian and non-Christian confessions. Part One consists of 65 documents (23.9 percent of the texts) on general policy, including for-

2 Red'kina. O. Yu. Veroispovednaia politika Vremennogo Pravitel'stva Rossii. Fevral' - oktiabr' 1917 g.: dis. ... kand. ist. nauk. Moscow, 1996; Sokolov A. V. Gosudarstvo i pravoslavnaia tserkov' v Rossii. Fevral' 1917 — ianvar' 1918 g.: dis. ... dokt. ist. nauk. St. Petersburg, 2014.

3 Dodonov B.F. Zhurnaly zasedanii Vremennogo pravitel'stva, 5 vols., Moscow, 2001-2011; Dodonov B.F. (ed.) Zapisi khoda zasedanii iuridicheskogo soveshchaniia pri Vremennom Pravitel'stve. Mart - oktiabr' 1917 goda. 2 vols. Moscow, 2018 (vol. 1, March - July, has thus far appeared).

4 Babkin M. A. (ed.) Konfessional'naia politika Vremennogo Pravitel'stva Rossii. Sbornik dokumentov. Moscow, 2018.

5 Babkin M.A. (ed.) Rossiiskoe dukhovenstvo i sverzhenie monarkhii v 1917 godu: materialy i arkhivnye dokumenty po istorii Russkoi Pravoslavnoi Tserkvi. $2^{\text {nd }}$ ed. Moscow, 2008.

6 Tallies will vary, depending on which "auxiliary" documents are counted. Here the total includes both the formal attachments ("prilozheniia") and the more substantial texts found in the commentary.

7 Dodonov B.F. Zhurnaly zasedanii Vremennogo pravitel'stva; Dodonov B.F. (ed.) Zapisi khoda zasedanii iuridicheskogo soveshchaniia pri Vremennom Pravitel'stve. Mart — oktiabr' 1917 goda.

8 The bibliography lists nine newspapers and fifteen journals. One has to wonder why some were chosen (e.g., a missionary journal, Chinese evangelist, published in Beijing) and others ignored (such as the church gazettes published in the dioceses of central European Russia). Indeed, it would also have been helpful to characterize these papers, or at least those which appear more frequently as a source. That is particularly true of Vserossiiskii tserkovno-obshchestvennyi vestnik, which became the main church organ in 1917; hence texts chosen from this periodical (pp.141-142, 195) bear an official, authoritative character. 
mal laws and related materials. Part Two offers materials dealing with sixteen religious groups, with most attention being given to the Russian Orthodox Church (23.5 percent), Roman Catholic Church (19.1 percent), and Lutheran Church (5.9 percent). A handful of documents pertain to other confessional groups: Edinoverie adherents, Georgian Orthodox, Old Believers, Uniates, Armenian Gregorian, Mennonites, Skoptsy, Baptists, Dukhobors, Muslims, Jews, Karaites, and Buddhists. Thematically, the documents reflect the Provisional Government's attempt to realize its initial promise of freedom of conscience by abrogating the discrimination that the ancien regime had gradually, but only partly, dismantled in its last decades. Concretely, the Provisional Government proceeded to declare an amnesty for religious, not just political offenses, to recast the oath, to establish new rules for conversion (especially with respect to minors), to update the laws on mixed marriage, and to construct a supra-confessional system of education (by nationalizing parish schools and restricting the mandate for religious instruction).

Compiling this volume was no easy task, not only because of the dispersed character of sources, but also because of an opaque legalistic style of formal law. As a rule, the laws tend to identify the laws to be changed, not by summarizing them, but by listing the numerical references in the Svod zakonov ("Digest of Laws") or other legal compilations. The first paragraphs of the decree on amnesty is typical (Fig.).

\section{№ 21. Указ Временного правительства «Об амнистии»}

6 марта 1917 г.

Во исполнение властных требований народной совести, во имя исторической справедливости и в ознаменование окончательного торжества нового порядка, основанного на праве и свободе, объявляется общая политическая амнистия ${ }^{1}$.

На сем основании Временное правительство постановило:

I. Освободить от ответственности и наказания со всеми оного последствия лиц, осуждённых за деяния, предусмотренные: 1) в главах второй и третьей и статьях 121, 128, 131 и 134 Уголовного уложения (Св. зак., т. XV, изд. 1909 г.), а также в статьях 121, 129, 130, 132, 163, 164,166 (ч. 2), 168 (ч. 3), 173 (ч. 4), 643 (ч. 2 и 3), 644 (ч. 4), 645 (ч. 4), 652 (ч. 3) сего Уложения, поскольку означенные в последних статьях деяния не имеют изменнического характера $\left.{ }^{2} ; 2\right)$ в главах первой, второй и третьей раздела второго, в разделе третьем, за исключением отделения второго главы второй означенного раздела, и в статьях 262-272, $273,273^{<1>}-275,276-280,281,281^{<1>}$, прим. 2 к ст. $286^{<1>}, 318-328,987$, $987^{<1>}, 1004-1020,1022$ (ч. 1 и 2), 1024, 1025, 1027-1029, 1031-1034<2>, $1034^{<4>}$ (п.п. 1-4), 1034 $4^{<5>}-1038^{<1>}, 1044^{<1>}, 1048,1066,1073,1074,1171$, $1358-1358^{<2>}, 1359^{<3>}-1359^{<10>}, 1423^{<1>}, 1424,1459$ (в отношении восстания против властей), 1564, 1565, 1568, 1570, 1575, 1576 Уложения о наказаниях уголовных и исправительных (Св. зак., т. XV, изд. 1885 и по Продолжениям $)^{3}$ и 3 ) в статьях $29^{<2>}, 33,39^{<4>}, 48^{<1>}, 48^{<5>}, 51^{<2>}, 51^{<3>}$, $51^{<4>}, 57^{<2>}-57^{<8>}, 58-59^{<1>}, 61-63$ (ч. 1 и 2), 142<2>, 155-168 (за исключением обязанности возмещения причинённого частному лесовладельцу ущерба) Устава о наказаниях, налагаемых мировыми судьями (Св. зак., т. XV, изд. 1885 и 1914 гг. $)^{4}$.

Fig. Ukase on Amnesty (6 March 1917) ${ }^{9}$

${ }_{9}$ Babkin M.A. (ed.) Konfessional'naia politika Vremennogo Pravitel'stva Rossii. P. 100. 
That style made such legislation economic in wording but utterly opaque to most readers. The compiler, to his credit, assiduously tracked down these references and prepared extensive commentaries, with profuse quotations of the specific articles being amended or abrogated. As a result, the commentary for some documents is much longer than the decree itself; in the case of a draft law on conversion, for example, the law consists of 556 words, but the commentary - with a blizzard of numerical legal references - is more than ten times as long (5,611 words). Not that the jurists in the Provisional Government were impeccable; in several instances the compiler found that the legal references were incorrect (for example, pp.62-63, 396-397). Given the morass of prerevolutionary law, one can well understand why the Bolsheviks - apart from antipathy toward the ancien regime - chose to repudiate outright that legal legacy and begin anew with "revolutionary zakonnost'”

This collection of documents affords a number of fascinating insights into the goals and problems of religious policy under the Provisional Government. At the very outset, the new regime affirmed its determination to guarantee freedom of conscience and in the following months went far toward recognizing the rights of non-Orthodox confessions. The government, mainly through its ober-prokuror V. N. L'vov, also supported revolutionary change in the Orthodox Church, not only by purging the most conservative prelates (often as alleged "Rasputin appointees), but also by actively promoting democratic ideals in ecclesiastical governance (pp. 182-183). But some of its initiatives, notably the nationalization of parish schools and retreat on religious education (Zakon bozhii) in state schools, provoked growing resistance from the Orthodox Church. But the Church was not the only religious organization to put pressure on the government; other confessions likewise lobbied on behalf of their special interests. In the end, creating a secular state and realizing full freedom of conscience proved very difficult and conflicted, making it increasingly difficult for the regime to achieve its initial promises and leading to what Babkin describes as "a certain contradictoriness" (p. 38) in confessional policy. Finally, the documents also underscore the financial pressures that profoundly impacted both religious organizations and the Provisional Government, impelling the former to seek assistance but leaving the latter with little capacity to respond. Financing the Church Council, long promised but underfunded, also became a source of tension between a bankrupt state and bankrupt Church $^{10}$.

While this volume affords rich insight into the priorities of confessional policy, it offers limited material on the dynamics of implementation and reception. To be sure, there are some exceptions, such as the telegram from Georgian clergy (p.265), the declarations by Old Believers (pp. 87-88) and Evangelicals (pp.124-125), and the telegram from the Simferopol' Congress of Crimean Muslims (pp.418-420). But such documents are relatively few and only whet the appetite for more, such as the appeals from Old Believers and Baptists that are cited but not reproduced (pp. 269, 410-411). As a result, this collection cannot shed light on the all-important question of implementation (did these laws really matter?) and reception (how did society, and specific groups, react to government policy?). By contrast, the first series in the massive collection of documents on the confessional policy of the Soviet state (covering the period 1917-1924) devotes one of its four

10 To elucidate the significance of the documents on financing the Pomestnyi sobor (pp. 228-231, 233234); see: Freeze G. L. The "Long" Church Council of 1917-1918: Institutional Crisis, Intellectual Capital // Ostkirchliche Studien. 2018. Vol. 67. P. 187-211. 
volumes to public, with 290 documents from religious associations, clergy, believers, and public organizations ${ }^{11}$.

To afford space for such material, it would have been advisable to re-prioritize what was included in this volume. Not all documents are equal; one might choose those that are more important and not readily available. For example, while some of the journals of the Provisional Government certainly merit inclusion, that is not true for all - especially since they are available in the Zhurnaly that were recently published. The same might be said of some sessions of the Juridical Council (currently being published). And perhaps certain kinds of documents, such as the multiple documents on the oath, might be pruned: while the fundamental decree of 9 June is essential (pp. 83-84), others - such as the oath for members of the Provisional Government (pp.112-113) and selected confessions (for example, pp.109-110, 119-20, 378-379, 381) - are already available in the Zhurnaly and add little. Some documents are also available elsewhere and not really germane, such as the list of members in the Provisional Government (pp.95-96). To be sure, compiling documents on "society's response" is a massive undertaking of its own, requiring painstaking archival research and a systematic study of the press - not only Orthodox periodicals, but the publications of other confessions and secular newspapers. Perhaps so ambitious a project might be the proper subject for a companion volume to this one.

Regrettable too is the lack of a subject and institutional index. Although this volume does have an index of personal names (enabling one to track all references to figures like V. N. L'vov, A. A. Kartashev, and S. A. Kotliarevskii), it is disappointing not to have systematic references to thematic issues (e.g., mixed marriages) and individual confessions. In the latter case, for example, the volume has a single document listed for "Jews," but in fact has some 86 references scattered throughout the documents. Even the organization of Part Two - on individual confessions - can be misleading: some documents in fact also concern other religious groups, not just the rubric of the confession under which the document appears (for example, pp.382-383, 394-395).

Finally, the volume has an excellent bibliography, listing most of the relevant books, dissertations, and articles produced in Russia since 1991 (and a few earlier ones) ${ }^{12}$. It is striking, however, that - apart from the Browder-Kerensky collection of documents ${ }^{13}$ it does not include the substantial scholarship produced in the West. It is, after all, important to overcome parochial tunnel vision and to consider the questions explored by non-Russian scholars. At the very least, that could help "historicize" the documents presented here; apart from referencing pre-revolutionary law, it is also important to frame the collection and individual documents, not just cite past law. For example, the text includes a decree (pp.72-73) abolishing legal disabilities imposed on clergy who voluntarily defrock (chiefly because of widowhood). That was a hot button issue for the parish clergy, but the commentary only tracks down the preparation of the text and quotes laws to be

11 Sorokin A.K. (ed.) Konfessional'naia politika sovetskogo gosudarstva 1917-1991. Vol.1, book 4. Moscow, 2018.

12 The bibliography of scholarly works (pp.502-509) is quite rich, but does not include some background studies, such as: Safronov A. A. Gosudarstvo i konfessii v pozneimperskoi Rossii. Moscow, 2017. - Missing too is a reference to: Kovyrzin K. V. Rossiiskaia Pravoslavnaia Tserkov' i poiski printsipov tserkovno-gosudarstvennykh otnoshenii posle Fevral'skoi revoliutsii: mart 1917g. - ianvar' 1918 g.: dis. ... kand. ist. nauk. Moscow, 2010.

13 Browder R. P., Kerensky A. F. (eds) The Russian Provisional Government, 1917: Documents. 3 vols. Stanford, 1961. - The collection has 41 documents on various religious groups (Vol.2. P. 803-839). 
changed (pp.73-75), without an explanation of how the discriminatory laws arose in the first place ${ }^{14}$. The foreign scholarship treats such critical issues (for example, freedom of conscience ${ }^{15}$ ), explores the historical dynamics behind religious politics (for example, the conflict between Baltic Germans and other ethnic groups in the Lutheran Church, pp. 385-387) $)^{16}$, explores the status of specific confessional groups ${ }^{17}$, and offers a comparative analysis of the confessional policy ${ }^{18}$.

Nevertheless, this volume is a monumental piece of work and a valuable source. It provides convenient access to many archival and rare printed sources, along with commentaries that decode the arcane and opaque legal references. One can only hope that a parallel volume on implementation and reception will follow.

\section{References}

Babkin M. A. (ed.) Confessional policy of the Provisional Board of Russia. Collection of documents. Moscow, ROSSPEN Publ., 2018, 558 p. (In Russian)

Babkin M.A. (ed.) Russian clergy and the overthrow of the monarchy in 1917: materials and archival documents on the history of the Russian Orthodox Church. $2^{\text {nd }}$ ed. Moscow, Indrik Publ., 2008, 627 p. (In Russian)

Browder R. P., Kerensky A.F. (eds) The Russian Provisional Government, 1917: Documents. 3 vols. Stanford, Stanford University Press, 1961, 1875 p.

Coleman H. J. Russian Baptists and Spiritual Revolution, 1905-1929. Bloomington, Indiana University Press, 2005, 305 p.

Dodonov B. F. (ed.) Records of the proceedings of the legal meeting under the Provisional Government. Mart oktiabr' 1917 goda. Vol. 1. Moscow, ROSSPEN Publ., 2018, 598 p. (In Russian)

Dodonov B. F. (ed.) Provisional Government Meeting Logs. 5 vols. Moscow, ROSSPEN Publ., 2001-2011. (In Russian)

Dunn D. J. The Catholic Church and Russia: Popes, Patriarchs, Tsar and Commissars. Burlington, Ashgate, 2004, $260 \mathrm{p}$.

Freeze G.L. The "Churching" of 1917: the church crisis and the parish revolution. Gosudarstvo, religiia, tserkov'v Rossii i za rubezhom. 2019, no. 1/2 (39), pp. 30-58. (In Russian)

${ }^{14}$ For the problem of widowed priests, see: Freeze G. L. The Parish Clergy in Nineteenth-Century Russia: Crisis, Reform, Counter-Reform. Princeton, 1983. P. 150-151, 200, 217-220, 276, 316-318, 400-401, 457.

15 See, for example, the recent monograph by: Werth $P$. The Tsar's Foreign Faiths: Toleration and the Fate of Religious Freedom in Imperial Russia. Oxford, 2014.

${ }^{16}$ Ketola M. The Nationality Question in the Estonian Evangelical Lutheran Church, 1918-1939. Helsinki, 2000; Weber K. Religion and Law in the Russian Empire: Lutheran Pastors on Trial, 1860-1917. Ph.D. thesis. New York, 2013; Raudsepp A. Das Rigaer Geistliche Seminar (1846-1918) in der estnischen Kulturgeschichte // Nordost-Archiv. Vol.7. 1998. P.497-532; Freeze Gr. Religious policy of the Russian Empire in the Baltics // Vestnik of Saint Petersburg University. History. 2017. Vol.62, iss. 4. P. 777-806.

17 Examples of such work for Baptists, Catholics, Edinoverie, and Muslims include: Coleman H.J. Russian Baptists and Spiritual Revolution, 1905-1929. Bloomington, 2005; Dunn D. J. The Catholic Church and Russia: Popes, Patriarchs, Tsar and Commissars. Burlington, 2004; White J.M. A Bridge to the Schism: Edinoverie, Russian Orthodoxy, and the Ritual Formation of Confessions, 1800-1918. Ph.D. thesis. Florence, 2014; Noack C. Muslimischer Nationalismus im russischen Reich: Nationsbildung und Nationalbewegung bei Tataren und Baschkiren, 1861-1917. Stuttgart, 2000.

18 For a comparative study of different confessional groups, see: Tuchtenhagen $R$. Religion als minderer Status. Die Reform der Gesetzgebung gegenüber religiösen Minderheiten in der verfaßten Gesellschaft des Russischen Reiches 1905-1917. Frankfurt am Main, 1995; Savelli D. (ed.) La Religion de l'Autre: Réactions et interactions entre religions dans le monde russe. Toulouse, 2009. For additional bibliography, see: Freeze G. L.: 1) Confessions in Imperial Russia: Analytical Overview of Historiography // Bylye gody. 2016. Vol.39. P.261-281; 2) Confessions in the Soviet Era: Analytical Overview of Historiography // Russian History. 2017. Vol. 44. P. 1-24. 
Freeze G.L. Confessions in Imperial Russia: Analytical Overview of Historiography. Bylye gody, 2016, vol. 39, pp. 261-281.

Freeze G. L. Confessions in the Soviet Era: Analytical Overview of Historiography. Russian History, 2017, vol. 44, pp. 1-24.

Freeze Gr. Religious policy of the Russian Empire in the Baltics. Vestnik of Saint Petersburg University. History, 2017, vol. 62, iss. 4, pp.777-806.

Freeze G. L. The "Long" Church Council of 1917-1918: Institutional Crisis, Intellectual Capital. Ostkirchliche Studien, 2018, vol.67, pp. 187-211.

Freeze G.L. The Parish Clergy in Nineteenth-Century Russia: Crisis, Reform, Counter-Reform. Princeton, Princeton University Press, 1983, 539 p.

Ketola M. The Nationality Question in the Estonian Evangelical Lutheran Church, 1918-1939. Helsinki, Suomen Kirkkohistoriallinen Seura, 2000, 361 p.

Kovyrzin K. V. Russian Orthodox Church 'and the search for the principles of church-state relations after the February's revolution: March 1917 - January '1918. Dis. ... kand. ist. nauk. Moscow, Pravoslavnyi Sviato-Tikhonovskii gumanitarnyi universitet Publ., 2010, 204 p. (In Russian)

Noack C. Muslimischer Nationalismus im russischen Reich: Nationsbildung und Nationalbewegung bei Tataren und Baschkiren, 1861-1917. Stuttgart, F. Steiner Verlag, 2000, 614 S.

Raudsepp A. Das Rigaer Geistliche Seminar (1846-1918) in der estnischen Kulturgeschichte Nordost-Archiv, 1998, vol. 7, pp. 497-532.

Red'kina. O. Yu. Religious policy of the Provisional Government of Russia. February' - October'1917. PhD thesis. Moscow, Moscow state University Publ., 1996, 151 p. (In Russian)

Safronov A. A. Gosudarstvo i konfessii v pozneimperskoi Rossii. Moscow, Prospect Publ., 2017, 352 p. (In Russian)

Savelli D. (ed.) La Religion de l'Autre: Réactions et interactions entre religions dans le monde russe. Toulouse, Universite de Toulouse Press, 2009, 526 p.

Sokolov A. V. The state and the Orthodox Church 'in Russia. February '1917 - January' 1918. Dis. ... d-ra ist. nauk. St. Petersburg, St. Petersburg University Press, 2014, 810 p. (In Russian)

Sorokin A. K. (ed.) Confessional's policy of the Soviet state 1917-1991. Vol. 1, book 1-4. Moscow, ROSSPEN Publ., 2018, 3009 p. (In Russian)

Tuchtenhagen R. Religion als minderer Status. Die Reform der Gesetzgebung gegenüber religiösen Minderheiten in der verfaßten Gesellschaft des Russischen Reiches 1905-1917. Frankfurt am Main, Peter Lang, 1995, 350 S.

Weber K. Religion and Law in the Russian Empire: Lutheran Pastors on Trial, 1860-1917. Ph.D. thesis. New York University Press, 2013, 410 p.

Werth P. The Tsar's Foreign Faiths: Toleration and the Fate of Religious Freedom in Imperial Russia. Oxford, Oxford University Press, 2014, 228 p.

White J.M. A Bridge to the Schism: Edinoverie, Russian Orthodoxy, and the Ritual Formation of Confessions, 1800-1918. Ph.D. thesis. Florence, European University Institute, 2014, 373 p.

Статья поступила в редакцию 9 августа 2019 г. Рекомендована в печать 2 декабря 2019 г.

Received: August 9, 2019

Accepted: December 2, 2019 